\title{
FUNCTIONAL BEHAVIOR OF TORTOISE HEMOGLOBIN Geochelone denticulata
}

\author{
TORSONI, M. A., ${ }^{1}$ STOPPA, G. R., ${ }^{2}$ TURRA, A. ${ }^{2}$ and OGO, S. H. ${ }^{2}$ \\ ${ }^{1}$ Universidade Braz Cubas, Mogi das Cruzes, SP, Brazil \\ ${ }^{2}$ Departamento de Bioquímica, Instituto de Biologia, Universidade Estadual de Campinas, Campinas, SP, Brazil \\ Correspondence to: Marcio Alberto Torsoni, Área da Saúde, Universidade Braz Cubas, \\ CEP 08773-380, Mogi das Cruzes, SP, Brazil, e-mail: torsoni@yahoo.com \\ Received Juny 26, 2001 - Accepted August 29, 2001 - Distributed November 30, 2002
}

(With 4 figures)

\begin{abstract}
The hemolysate from Geochelone denticulata contains two main hemoglobin components, as shown by ion exchange chromatography and polyacrylamide gel electrophoresis (PAGE). Electrophoresis under dissociating conditions showed three types of globin chains. The apparent molecular mass, as determined by gel filtration on Sephadex G-200, was compatible with tetrameric Hb, which was unable to polymerize. The G. denticulata $\mathrm{Hb}$ has a $\mathrm{P} 50$ value of $9.56 \mathrm{~mm} \mathrm{Hg}$ at $\mathrm{pH} 7.4$. The $\mathrm{Hb}$ oxygenation appears to be under the control of organic phosphates and hydrogen ion since it is strongly affected by those species. In the presence ATP or IHP the P50 values increased to $29.51 \mathrm{~mm} \mathrm{Hg}$ and $54.95 \mathrm{~mm} \mathrm{Hg}$, respectively, at $\mathrm{pH}$ 7.4. The $\mathrm{n} 50$ was generally lower than 1.5 in stripped $\mathrm{Hb}$, suggesting a dissociation of tetramers. In the presence of organic phosphates n50 values increased to approximately 2.5 . The Bohr effect was evident in oxygen equilibrium experiments. The hematocrit (32\%) and $\mathrm{Hb}$ concentration (5.7 $\mathrm{mM}$ as heme) of G. denticulata blood were substantially larger than those of G. carbonaria, but the methemoglobin levels were similar in both species, approximately $1 \%$. Thus, the oxygen capacity of blood appears to be higher in G. denticulata than in G. carbonaria, particularly considering the functional properties of their $\mathrm{Hbs}$, which would guarantee the survival of animals.
\end{abstract}

Key words: hemoglobin, $\mathrm{Hb}-\mathrm{O}_{2}$ affinity, Bohr effect, Geochelone denticulata, tortoise.

\section{RESUMO}

\section{Comportamento funcional da hemoglobina da tartaruga Geochelone denticulata}

$\mathrm{O}$ hemolisado de Geochelone denticulata contém dois componentes principais, de acordo com a cromatografia de troca iônica e PAGE. Eletroforese sob condições dissociantes mostrou 3 tipos de cadeias de globina. A massa molecular aparente, determinada pela filtração em gel sobre Sephadex G-200, foi compatível com $\mathrm{Hb}$ tetramérica que foi incapaz de polimerizar. A $\mathrm{Hb}$ de $G$. denticulata tem valor de P50 de 9,56 mm Hg em pH 7,4. A oxigenação da Hb parece estar sob controle de fosfatos orgânicos e íons hidrogênio, uma vez que ela é fortemente afetada por essas espécies. Na presença de ATP ou IHP, os valores de P50 aumentaram para $29,51 \mathrm{~mm} \mathrm{Hg}$ e $54,95 \mathrm{~mm} \mathrm{Hg}$, respectivamente, a pH 7,4. O n50 foi geralmente menor que 1,5 na Hb stripped, sugerindo dissociação de tetrâmeros. Na presença de fosfatos orgânicos, os valores de n50 aumentaram para aproximadamente 2,5. O efeito Bohr foi evidente nos experimentos de equilíbrio com oxigênio. O hematócrito de $32 \%$ e a concentração de $\mathrm{Hb}$ de $5,7 \mathrm{mM}$ em heme no sangue de $G$. denticulata foram substancialmente maiores do que da $G$. carbonaria, mas os níveis de metahemoglobina foram similares em ambas as espécies, aproximadamente $1 \%$. Portanto, a capacidade de oxigenação do sangue parece ser maior na G. denticulata, particularmente considerando as propriedades funcionais da $\mathrm{Hb}$, que garantiria a sobrevivência dos animais.

Palavras-chave: hemoglobina, afinidade $\mathrm{Hb}-\mathrm{O}_{2}$, efeito Bohr, Geochelone denticulata, tartaruga. 


\section{INTRODUCTION}

In general, the functional properties of hemoglobins (Hbs) appear to be well adapted to meet the different metabolic needs of animals and their environmental constraints. To examine the structure and function of $\mathrm{Hb}$ from closely related species of turtle, G. denticulata $\mathrm{Hb}$ was studied and compared with that of $G$. carbonaria $\mathrm{Hb}$ (Torsoni et al., 1997). These two species of turtle belong to the Testudinidae family. G. denticulata may be distinguished from G. carbonaria by a more drab coloration of its carapace, although coloration alone is sometimes not sufficient to distinguish between the two species. G. carbonaria is typically found in grassland or savanna ecosystems while $G$. denticulata is restricted to rain forests (Fretey, 1978; Castaño et al., 1981).

Turtle Hbs exhibit many properties, which differ from those of other vertebrates. Svedberg \& Hedenius (1934) studied the sedimentation characteristics of various hemoglobins. They found that mammalian, avian and fish hemoglobins were uniform in size with sedimentation coefficient corresponding to molecular weighs of $60-70 \mathrm{kD}$. Larger molecules were found in hemolysates of amphibians and reptiles red cells and were formed by polymerized Hb. Sullivan \& Riggs (1967a, b) demonstrated that many turtle $\mathrm{Hbs}$ readily polymerize under oxidizing conditions. The polymeric $\mathrm{Hb}$ may be formed by disulfide bonds among tetramers or by the tetramer-tetramer selfassociation, which was found in chicken Hb (Riggs, 1998). Turtle Hbs also differ from mammalian Hbs in their number of components. Most turtles show two major components and one or more minor $\mathrm{Hb}$ (Sullivan \& Riggs, 1967a).

The role of organic phosphates as allosteric modulators of oxygen binding to vertebrate $\mathrm{Hbs}$ is well established, and is associated with conformational change in the protein (Benesch et $a l ., 1968)$. The oxygen binding properties of turtle Hbs are also known to be affected to different degrees by organic phosphates, but the physiological significance of this molecular polymorphism is not yet fully understood. Adenosine triphosphate (ATP) appears to be the main organic phosphate allosteric modulator in reptiles and is present in high concentrations in the red blood cells of a number of species. The erythrocytes of birds and reptiles may also contain inositol pentaphosphate (Coates, 1975; Bartlett, 1976; Davis, 1991).

The present paper reports on the $\mathrm{Hb}-\mathrm{O}_{2}$ affinity and cooperation of purified $\mathrm{Hb}$ from $G$. denticulata, including the response to $\mathrm{pH}$ and organic polyphosphates. The polymerization of $\mathrm{Hb}$ by intermolecular disulfide bridges and extensive formation of mixed disulfides (glutathionyl-Hb) has been reported for turtles (Reischl, 1986), and depends on the occurrence of externally positioned reactive thiol groups. Hb from $G$. denticulata, however, does not polymerize. For this reason we also assessed the availability of $\mathrm{SH}$ groups in $\mathrm{Hb}$ from this species.

\section{MATERIAL AND METHODS}

\section{Preparation of Hb solutions}

Blood was obtained from adult $G$. denticulata, by cardiac puncture using a cooled syringe containing $100 \mu \mathrm{l}$ of sodium heparin $(5,000$ $\mathrm{IU} / \mathrm{ml}$ ) in $0.9 \% \mathrm{NaCl}$ per $5 \mathrm{ml}$ of blood. Prior to sampling, the puncture site was disinfected with ether and a local anesthetic (lidocaine) was applied. The hematocrit was estimated by standard methods. Red blood cells were separated by centrifugation for $10 \mathrm{~min}$ at $1,100 \mathrm{~g}$ and washed three times with $10 \mathrm{vol}$ of cold $1.7 \% \mathrm{NaCl}(\mathrm{w} / \mathrm{v})$, containing $1 \mathrm{mM}$ ethylenediamine tetraacetic acid (EDTA) and then lysed in $25 \mathrm{mM}$ Tris-HCl-1 mM EDTA, pH 8.5, as previously described (Ogo et al., 1979). The stroma was removed by centrifugation for $5 \mathrm{~min}$ at $15,000 \mathrm{~g}$, and the supernatant was stripped of salts and small molecules by passing the hemolysate through a $2.0 \mathrm{~cm} \times 50 \mathrm{~cm}$ column of Sephadex G-25 equilibrated with the Tris-EDTA buffer above described. The purified $\mathrm{Hb}$ was used as soon as possible after preparation and was not frozen.

The $\mathrm{Hb}$ concentration in hemolysates was estimated spectrophotometrically using the $\mathrm{mM}$ extinction coefficient for human $\mathrm{Hb}$ A (Antonini \& Brunori, 1971) or as cyanometHb using Drabkin reagent $\left(100 \mathrm{mg} \mathrm{NaCN}\right.$ and $300 \mathrm{mg} \mathrm{K}_{3} \mathrm{FeCN}_{6}$ dissolved in $1 \mathrm{~L}$ of water). The $\mathrm{Hb}$ concentration $(\mathrm{mM})$ was calculated using an $\varepsilon m \mathrm{mM}$ of $11.5 \mathrm{mM}^{-1}$ $\mathrm{cm}^{-1}$ at $540 \mathrm{~nm}$ (Winterbourn, 1990). The methemoglobin concentration ( $\mathrm{mM}$ ) was estimated based on the absorbances at $577 \mathrm{~nm}$ and $630 \mathrm{~nm}$ (Winterbourn, 1990) as follows:

$[$ Methemoglobin $]=279 \mathrm{~A}_{630}-3.04 \mathrm{~A}_{577}$ 
Hemoglobin concentrations were expressed per heme group.

\section{Ion exchange chromatography}

Stripped $\mathrm{Hb}$ (about $100 \mathrm{mg}$ of protein) was dialyzed against $25 \mathrm{mM}$ Tris- $\mathrm{HCl}$ plus $1 \mathrm{mM}$ EDTA, $\mathrm{pH} 8.3$, and applied to a column $(1.8 \mathrm{~cm} \mathrm{x}$ $20 \mathrm{~cm}$ ) of DEAE-cellulose equilibrated with the above buffer. The $\mathrm{Hb}$ was eluted with the same buffer by decreasing the $\mathrm{pH}$ from 8.3 to 6.5 , in a gradient fashion. The separation was carried out at $20^{\circ} \mathrm{C}$ and the elution profile monitored at $541 \mathrm{~nm}$.

\section{Polyacrylamide gel electrophoresis (PAGE)}

Identification of the $\mathrm{Hb}$ components was achieved by slab PAGE at room temperature using stacking gels of $3.5 \%$ acrylamide and running gels of $7.5 \%$ acrylamide. The gels were run at $1.5 \mathrm{~mA} /$ sample for about $4 \mathrm{~h}$ using $50 \mathrm{mM}$ Tris-glycine, $\mathrm{pH} 8.9$, in the upper buffer reservoir and $50 \mathrm{mM}$ Tris- $\mathrm{HCl}, \mathrm{pH} 8.1$, in the lower buffer reservoir (Davis, 1964; Ornstein, 1964). The samples for electrophoresis were prepared by mixing $20 \mu \mathrm{l}$ of $\mathrm{Hb}$ solution (about $50 \mu \mathrm{g}$ of protein), $20 \mu \mathrm{l}$ of upper electrode buffer, $20 \mu \mathrm{l}$ of glycerol and $20 \mu \mathrm{l}$ of lower electrode buffer. The $\mathrm{Hb}$ bands were detected using $0.05 \%$ Coomassie brilliant blue $\mathrm{G}$ in acetic acid:methanol:water (1:2:4, v/v) and destained in a solution containing $7 \%$ acetic acid and $14 \%$ methanol.

Globin chains from $30 \mu \mathrm{g}$ samples of $\mathrm{Hb}$ were separated by PAGE under dissociating conditions (Alter et al., 1980) using $12 \%$ polyacrylamide gels containing $6 \mathrm{M}$ urea and $2 \%$ Triton $\mathrm{X}-100$ in $5 \%$ acetic acid. The gels were run at 8 $\mathrm{mA}$ for $18 \mathrm{~h}$ and then stained for $24 \mathrm{~h}$ in $0.05 \%$ Coomassie blue followed by destaining in a $7 \%$ acetic acid-30\% methanol solution.

\section{Gel filtration}

The apparent molecular masses of the Hbs were determined by gel filtration on a column (2.5 $\mathrm{cm} \times 100 \mathrm{~cm}$ ) of Sephadex G-200 equilibrated at $20^{\circ} \mathrm{C}$ with $50 \mathrm{mM}$ Tris- $\mathrm{HCl}$ buffer, $\mathrm{pH} 7.4$, containing $1 \mathrm{mM}$ EDTA. Samples of $\mathrm{Hb}(2.0 \mathrm{ml}$, $12 \mathrm{mg} / \mathrm{ml}$ ) were applied and the absorbance of the eluate was read in a Hitachi U2000 spectrophotometer at $541 \mathrm{~nm}$. The void volume (Vo) was determined using blue-dextran. The column was calibrated with dimeric L. miliaris (snake) $\mathrm{Hb}$, $32 \mathrm{kDa}$ (Matsuura et al., 1987), tetrameric human $\mathrm{Hb}(64 \mathrm{kDa})$ and catalase $(240 \mathrm{kDa})$. The parameters Vo, Vt and Ve were used to calculate the constant Kav, as previously described (Laurent \& Killander, 1964). The data were plotted as Kav of the marker proteins and unknown samples vs. molecular mass.

\section{Oxygen equilibrium studies}

Oxygen equilibria of stripped hemolysates were carried out at $25^{\circ} \mathrm{C}$ by the tonometric method (Riggs \& Wolbach, 1956). Hb solutions (50-60 $\mu \mathrm{M}$ as heme) were brought to $0.05 \mathrm{M}$ ionic strength in Tris buffer containing $1 \mathrm{mM}$ EDTA in a $\mathrm{pH}$ range of 7.0 to 8.4. Absorbance measurements were made in a Hitachi U2000 spectrophotometer over a wavelength range of 500-600 nm. Oxygen binding equilibrium curves were determined in the absence and presence of $2 \mathrm{mM}$ inositol hexaphosphate (IHP) or $2 \mathrm{mM}$ ATP to test for allosteric effects. IHP (dodecasodium salt from corn) and ATP (disodium salt, from yeast) were purchased from Sigma (St. Louis, USA). The Bohr effect $(\Delta \log \mathrm{P} 50 / \Delta \mathrm{pH})$ was estimated by the difference in $\log$ P50 values from $\mathrm{pH} 7.0$ to $\mathrm{pH}$ 8.0. The Hill coefficient, n50, was determined using Hill plots at saturation values between $30 \%$ and $70 \%$. Hb solutions containing more than $7 \%$ of methemoglobin were not used for oxygen equilibrium experiments.

\section{Thiol titration}

Titration of the reactive sulphydryl groups of $\mathrm{Hb}$ was performed at $25^{\circ} \mathrm{C}$ using 2,2'-dithiobis (5-nitropyridine) (DTNP). To $1.5 \mathrm{ml}$ of recently collected stripped $\mathrm{Hb}$ solution $(5-15 \mu \mathrm{M}$, as heme) in $0.1 \mathrm{M}$ phosphate buffer $\mathrm{pH} 8.0$ was added 30 $\mu l$ of $5 \mathrm{mM}$ DTNP $(3.1 \mathrm{mg} / \mathrm{ml}$ in ethanol) and after $20 \mathrm{~min}$, the A386 nm was measured against a blank containing $\mathrm{Hb}$ at the same concentration. The absorption of DTNP in phosphate buffer was subtracted and the number of thiol groups was then calculated using an $\varepsilon \mathrm{mM}$ of $14.0 \mathrm{mM}^{-1} \mathrm{~cm}^{-1}$ at 386 nm (Winterbourn, 1990).

\section{RESULTS}

Hematocrit, blood $\mathrm{Hb}$ concentration and methemoglobin levels were determined for 9 
specimens of $G$. denticulata. The hematocrit value of $32 \pm 2 \% \mathrm{v} / \mathrm{v}$ corresponded to a $\mathrm{Hb}$ concentration of $5.7 \pm 0.2 \mathrm{mM}$ (as heme) or $9.1 \mathrm{~g} \%$. The methemoglobin content in freshly collected hemolysate was $1.0 \pm 0.1 \%$ of the total $\mathrm{Hb}$.

Chromatographic separation of the total hemolysate on DEAE-cellulose resulted in two main components labeled $\mathrm{Hb} 1(75 \%)$ and $\mathrm{Hb} 2$ (25\%), based on their order of elution (Fig. 1). Identification of the $\mathrm{Hb}$ components was performed by PAGE (Fig. 2).

Gel filtration studies indicated that $G$. denticulata $\mathrm{Hb}$ was not capable of forming polymers and eluted as a single peak corresponding to an apparent molecular mass of about $64 \mathrm{kDa}$. Aged $\mathrm{Hb}$ solutions (7 days after blood collection) exhibited a similar elution profile.

The globin composition of total hemolysate and of the individual components was analyzed by PAGE under dissociating conditions. The total hemolysate consisted of three globin chains named as G1, G2 and G3: component Hb1, consisted of G1 and G3 and component Hb2 contained G1 + G2 globin chains (Fig. 3).

The content of sulphydryl groups/tetrameric $\mathrm{Hb}$ as determined in freshly collected stripped hemolysate was $1.7 \pm 0.3(\mathrm{n}=5)$ available thiol groups based on titration with DTNP.

The oxygen binding properties of $G$. denticulata $\mathrm{Hb}$ were investigated in stripped hemolysate at $\mathrm{pH}$ values ranging from 7.0 to 8.4 and in the presence of $2 \mathrm{mM}$ ATP and $2 \mathrm{mM}$ IHP (Table 1, Fig. 4). The partial pressure of oxygen at half saturation (P50) at $25^{\circ} \mathrm{C}$ was $9.56 \mathrm{~mm} \mathrm{Hg}$ at $\mathrm{pH} 7.4$.

The influence of the heterotropic effectors ATP and IHP on oxygen affinity is illustrated by the decrease in $\mathrm{O}_{2}$ affinity: the values of P50 increased to 29.51 and $54.95 \mathrm{~mm} \mathrm{Hg}$, respectively. Minimal oxygen affinity was observed at the lower pH values.

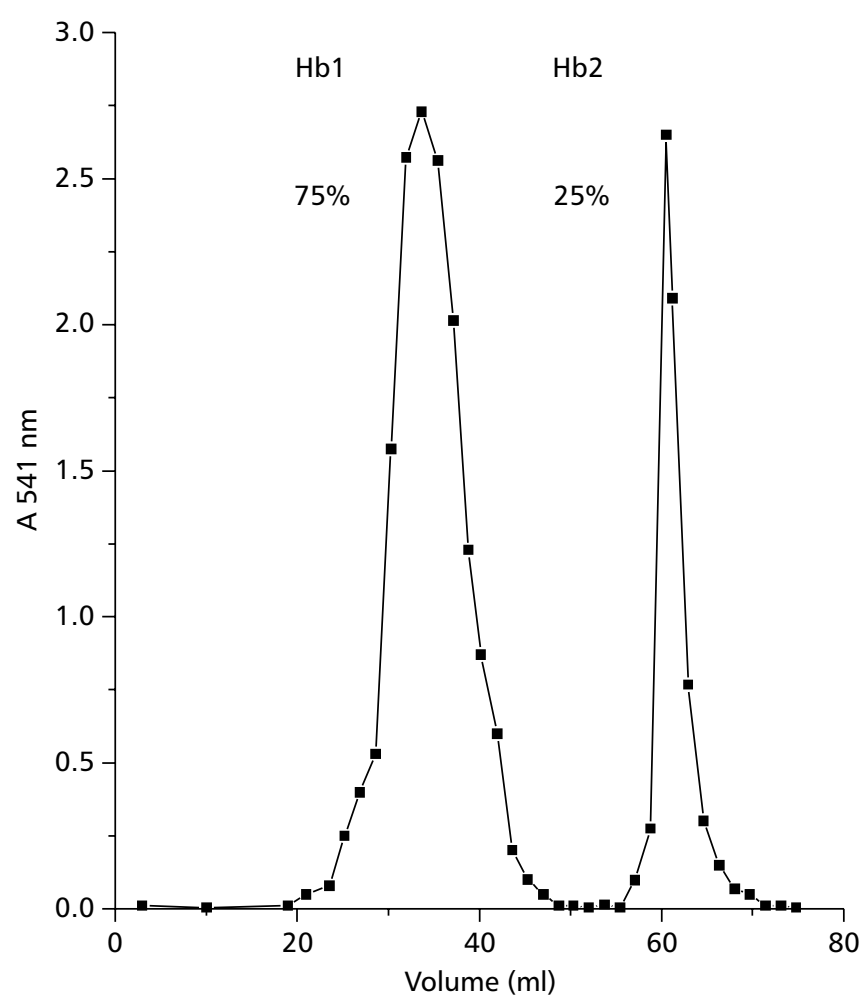

Fig. 1 - Elution profile of stripped $G$. denticulata $\mathrm{Hb}$ from a column of DEAE-cellulose eluted with $25 \mathrm{mM}$ Tris- $\mathrm{HCl}$ containing $1 \mathrm{mM}$ EDTA using a pH gradient of 8.3-6.5. The absorbance was determined at $541 \mathrm{~nm}$. $\mathrm{Hb} 1$ and $\mathrm{Hb} 2$ indicate the two main fractions obtained (based on the order of elution). 


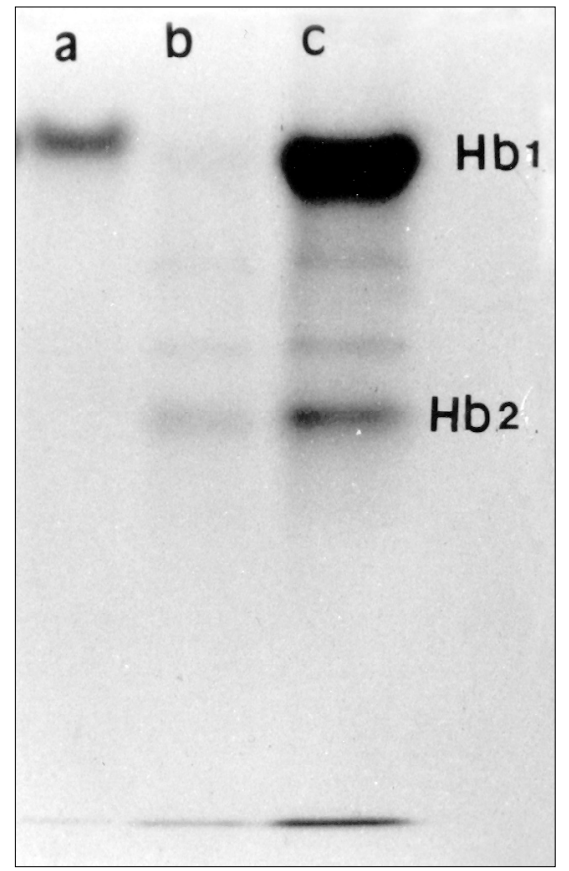

Fig. 2 - PAGE profile of G. denticulata $\mathrm{Hb}$ at $\mathrm{pH}$ 8.9. The gels were stained with Coomassie blue. (a) and (b) Hb1 and $\mathrm{Hb} 2$, respectively, (c) total hemolysate.

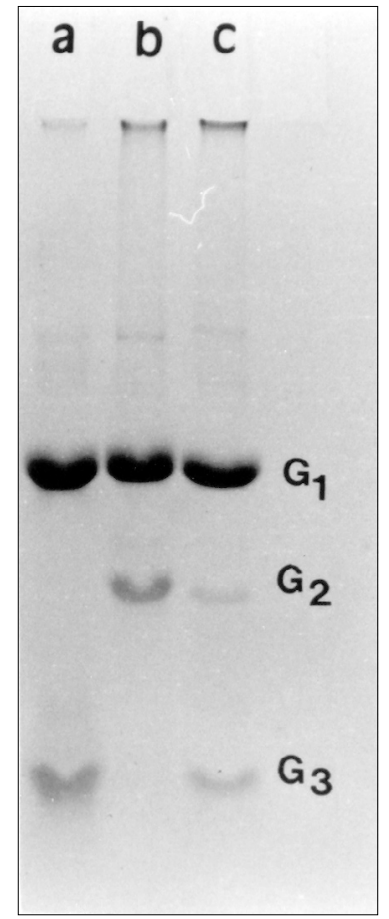

Fig. 3 - PAGE of the globin chains of $G$. denticulata $\mathrm{Hb}$ in the presence of Triton X-100 and urea, at acid pH. The gels were stained with Coomassie blue. (a) and (b) $\mathrm{Hb} 1$ and $\mathrm{Hb} 2$, respectively, (c) total hemolysate. 
The Bohr effect $(\Delta \log \mathrm{P} 50 / \Delta \mathrm{pH})$ for stripped Hb measured at $\mathrm{pH} 7.0$ to 8.0 , was -0.57 ; the addition of $2 \mathrm{mM}$ ATP or $2 \mathrm{mM}$ IHP resulted in values of -0.66 and -0.69 , respectively (Fig. $4)$. The apparent cooperativity between subunits suggested by the Hill coefficient (n50) is shown in the inset of Fig. 4. In stripped $\mathrm{Hb}$, the Hill coefficient was little influenced by $\mathrm{pH}$; the $\mathrm{n} 50$ values varied $1.0-1.5$ at $\mathrm{pH}$ from 7.0 to 8.4 . In the range of $\mathrm{pH}$ studied the addition of $2 \mathrm{mM}$ ATP or $2 \mathrm{mM}$ IHP induced an increase in n50 values to approximately $2.0-2.5$.

\section{DISCUSSION}

The complexity of chelonian Hbs compared to that of mammalians is well demonstrated by the variety $\mathrm{Hb}$ components observed in hemolysates from several turtle species (Sullivan \& Riggs, 1967a; Rucknagel et al., 1984; Torsoni et al., 1997). The chromatographic profile (Fig. 1) and electrophoretic pattern (Fig. 2) of fresh total hemolysate from $G$. denticulata showed two main components ( $\mathrm{Hb} 1$ and $\mathrm{Hb} 2$ ). An identical pattern was obtained for aged $\mathrm{Hb}$ solutions on PAGE. This finding contrasts with that for $G$. carbonaria in which the fresh $\mathrm{Hb}$ presented a complex electrophoretical pattern and varied with the duration of storage, demonstrating its polymerization capacity (Torsoni et al., 1997). The polymerization may be formed by disulfide bridges among tetramers. Disulfide bonds may also yield mixed disulfide between $\mathrm{Hb}$ and non-protein $\mathrm{SH}$ groups that are demonstrated by the high electrophoretical heterogeneity of G. carbonaria $\mathrm{Hb}$ (Torsoni et al., 1996).

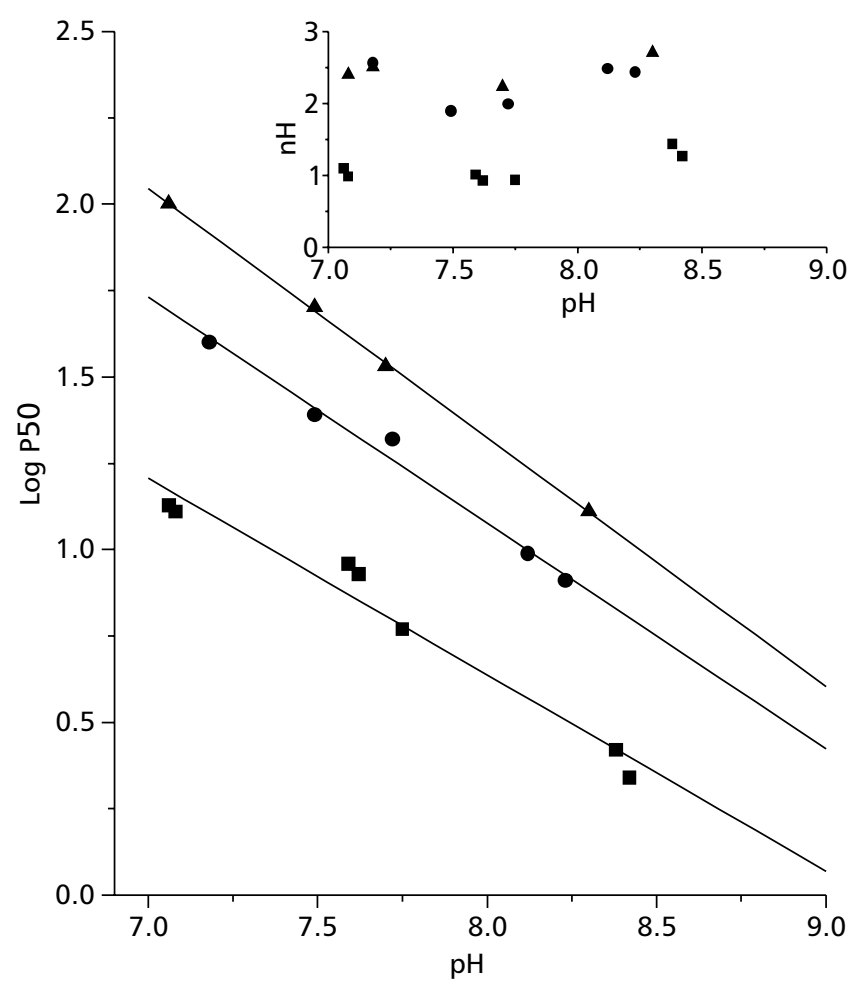

Fig. 4 - Oxygen affinity ( $\log \mathrm{P} 50)$ and $\mathrm{n} 50$ values for $\mathrm{G}$. denticulata $\mathrm{Hb}$ at $25^{\circ} \mathrm{C}$ as a function of $\mathrm{pH}$. The $\mathrm{Hb}$ solutions were buffered against $50 \mathrm{mM}$ Tris- $\mathrm{HCl}+1 \mathrm{mM}$ EDTA. (-a), stripped $\mathrm{Hb} ;(\bullet-), \mathrm{Hb}+2 \mathrm{mM} \mathrm{ATP} ;(\boldsymbol{\Delta}) \mathrm{Hb}+2 \mathrm{mM}$ IHP. The lines were obtained by linear regression. 
In order to examine the structural differences between the main $\mathrm{Hb}$ components ( $\mathrm{Hb} 1, \mathrm{Hb} 2)$ of $G$. denticulata PAGE was performed under dissociating conditions. Three polypeptide subunits (G1, G2 and G3) were obtained from the total hemolysate. The globin chains of each component purified by ion exchange chromatography were $\mathrm{G} 1+\mathrm{G} 3$ for $\mathrm{Hb} 1$ and $\mathrm{G} 1+\mathrm{G} 2$ for $\mathrm{Hb} 2$ (Fig. 3). Thus, the two main $\mathrm{Hb}$ components possess the G1 globin chain, with the second globin chain dissimilar, showing a structural difference between them, as it also occurs in G. carbonaria (Torsoni et al., 1997). A similar situation has been observed in the turtles $C$. picta belli and P. hillarii, (Rucknagel et al., 1984) in which the two $\mathrm{Hb}$ components possess the same $\beta$ chain.

Gel filtration studies indicated that $G$. denticulata $\mathrm{Hb}$ did not polymerize, although polymerization is frequently seen in turtle Hbs (Sullivan \& Riggs, 1967a; Reischl, 1989), including that of G. carbonaria (Torsoni et al., 1997), which is able to form aggregates larger than tetramers. Polymerization of turtle $\mathrm{Hb}$ may occur in vivo under conditions of environmental stress and in vitro, after hemolysis (Riggs et al., 1964; Sullivan \& Riggs, 1964). The ability of vertebrate Hbs to polymerize depends on the availability of cysteinyl residues. Only 1.7 SH groups per $\mathrm{Hb}$ (tetramer) were observed for $G$. denticulata. This value of 1.7 per $\mathrm{Hb}$ tetramer would reflect the different number of available SH group in different polypeptide chain. The free SH probably corresponds to cysteine $\beta 93$, a highly conserved residues also found in human $\mathrm{Hb}$; the latter also does not form disulfide bonds. In contrast, G. carbonaria $\mathrm{Hb}$ consists of four $\mathrm{SH}$ groups/Hb (tetramer) (Torsoni et al., 1996), which would explain the ability of this protein to polymerize.
The $\mathrm{Hb}-\mathrm{O}_{2}$ affinities of $G$. denticulata $\mathrm{Hb}$ (expressed as $\log$ P50, i.e., the logarithm of oxygen partial pressure required to half-saturate $\mathrm{Hb}$ ) in the absence and presence of allosteric effectors (ATP, IHP) are shown in Table 1 and Fig. 4. The oxygenation properties of $\mathrm{Hbs}$ from different animals vary and are related with the metabolism and environment of the animal from which the $\mathrm{Hb}$ derives (Riggs, 1964). The intrinsic $\mathrm{Hb}-\mathrm{O}_{2}$ binding properties of $G$. denticulata, yielded P50 values higher than those of G. carbonaria under the same experimental conditions (Torsoni et al., 1997). Indeed, $G$. denticulata $\mathrm{Hb}$ showed a low $\mathrm{O}_{2}$ affinity with P50 about $9.56 \mathrm{~mm} \mathrm{Hg}$, versus $6.30 \mathrm{~mm} \mathrm{Hg}$ for G. carbonaria $\mathrm{Hb}$, at $\mathrm{pH}$ 7.4. In the presence of saturating concentrations $(2 \mathrm{mM})$ of the allosteric effectors ATP and IHP, higher P50 values for $G$. denticulata $\mathrm{Hb}$ oxygenation (29.51 and $54.95 \mathrm{~mm}$ $\mathrm{Hg}$, respectively versus 14.10 and $20.12 \mathrm{~mm} \mathrm{Hg}$, respectively, for $G$. carbonaria at $\mathrm{pH} 7.4$ ) were observed, suggesting that the release of oxygen from $\mathrm{Hb}$ to tissue occurs at a higher $\mathrm{O}_{2}$ pressure in this species than in G. carbonaria (Tosoni et al., 1997).

ATP is the major allosteric cofactor present in the adult turtle erythrocytes (Coates, 1975; Bartlett, 1976; Davis, 1991). IHP, which is considered one of most powerful effectors of $\mathrm{Hb}$ affinity (Arnone $\&$ Perutz, 1972) showed greater effect on the reduction of oxygen affinity of turtle $\mathrm{Hb}$. Nevertheless, IHP, which was used as a substitute for inositol pentaphosphate (IPP) to test the allosteric effect on G. denticulata $\mathrm{Hb}$, is not a physiological phosphate within turtle red blood cells; instead, several authors (Bartlett, 1976; Bartlett, 1980; Lutz \& Lapenas, 1982; Davis, 1991) found IPP in the erythrocytes of adult turtles, usually at a concentration of 5-10 times lower than ATP. Therefore, in vivo, the Hb oxygen affinity would be lower than in stripped $\mathrm{Hb}$.

TABLE 1

Summary of oxygen equilibria for Geochelone denticulata $\mathrm{Hb}$.

\begin{tabular}{|l|c|c|c|c|}
\hline \multirow{2}{*}{\multicolumn{1}{|c|}{ Samples }} & \multicolumn{3}{|c|}{ P50 (mm Hg) } & \multirow{2}{*}{ Log P50/ $\Delta$ pH (7.0-8.0) } \\
\cline { 2 - 4 } & pH 7.0 & pH 7.4 & pH 8.0 & -0.57 \\
\hline Stripped Hb & 15.85 & 9.56 & 4.37 & -0.66 \\
\hline $\mathrm{Hb}+2 \mathrm{mM} \mathrm{ATP}$ & 53.70 & 29.51 & 11.75 & -0.69 \\
\hline $\mathrm{Hb}+2 \mathrm{mM} \mathrm{IHP}$ & 104.71 & 54.95 & 21.38 & \\
\hline
\end{tabular}

Data obtained from Fig. 4. 
A large Bohr effect $(\Delta \log \mathrm{P} 50 / \Delta \mathrm{pH})$ for $\mathrm{O}_{2}$ binding was observed for G. denticulata $\mathrm{Hb}$ (Table 1, Fig. 4) and showed a similar amplitude with purified $\mathrm{Hb}$ alone and in the presence of ATP or IHP, indicating that the $\mathrm{pH}$ dependence of the oxygen affinity was little affected by the presence of organic phosphates. The large Bohr effect and the sensitivity of P50 values to phosphate modulations suggest that the regulation of the $\mathrm{Hb}$ $\mathrm{O}_{2}$ binding may involve factors which control the blood $\mathrm{pH}$ and the concentrations of organic phosphates in red blood cells as occurs in almost all vertebrate $\mathrm{Hb}$. The Bohr effect values were similar to those displayed by $G$. carbonaria $\mathrm{Hb}$, and were somewhat higher than for Testudo graeca. In the latter species, the Bohr shift apparently plays only a small role in modifying the $\mathrm{Hb}-\mathrm{O}_{2}$ affinity in situations of apnoea (Burggren et al., 1977).

The oxygen binding process for $G$. denticulata $\mathrm{Hb}$ did not appear to be auto-catalytic as was also the case for G. carbonaria (Torsoni et al., 1997) and most other turtle species (Burggren et al., 1977). The Hill coefficient was generally lower than 1.5 , suggesting a dissociation of tetramers to dimers, as occurs in some species of snakes accompanying the oxygenation in the absence of but not in the presence of ATP or IHP (Matsuura et al., 1987; Focesi et al., 1990; Bonafé et al., 1999). In the presence of the physiological allosteric effector, ATP, the n50 values increased to approximately 2.0-2.5 (inset Fig. 4). Similar values were found in the presence of IHP. It seems, therefore, that the oxygen binding property of $G$. denticulata $\mathrm{Hb}$ is cooperative in vivo.

As far as these results could be extended to in vivo conditions, the oxygen discharge to the tissues and the binding in the pulmonary level would be greatly facilitated both by decrease of $\mathrm{pH}$ and by change of ATP level. The decrease of $\mathrm{pH}$ would make the nucleotide bind more strongly to the hemoglobin and, therefore, easily release the gas due to the high decrease of the oxygen binding constant to the protein.

The volume of oxygen carried to the tissue by a unit of blood depends upon a number of factors, including the amount of $\mathrm{Hb}$ present in the blood and the proportion of $\mathrm{Hb}$ that is actually functioning in oxygen transport. Thus, the hematocrit, $\mathrm{Hb}$ concentration and methemoglobin levels are important parameters for evaluating the oxygen capacity of the tortoise blood. The high methemoglobin levels described for certain turtle species (Reischl, 1989), may have considerable physiological importance since oxidized $\mathrm{Hb}$ does not bind oxygen reversibly.

The hematocrit (32\%) and $\mathrm{Hb}$ concentration (5.7 $\mathrm{mM}$ as heme) of $G$. denticulata blood were substantially larger than those of $G$. carbonaria (Torsoni et al., 1997), but the methemoglobin levels were similar in both species, approximately $1 \%$. Thus, the oxygen capacity of $G$. denticulata blood appears to be higher than of $G$. carbonaria, particularly considering the functional properties of $\mathrm{Hb}$, which provide the release of oxygen from $\mathrm{Hb}$ to the tissue at higher $\mathrm{O}_{2}$ pressure in $G$. denticulata.

Acknowledgments - This research was supported by grants from FAPESP (94/0174-6), FAEP (0534/93) and CNPq (520110/94-3).

\section{REFERENCES}

ALTER, B. P., GOFF, S. C., EFREMOV, G. D., GRAVELY, M. E. \& HUISMAN, T. H., 1980, Globin chain electrophoresis: a new approach to the determination of the $\mathrm{G} \gamma / \mathrm{A} \gamma$ ratio in fetal haemoglobin and to studies of globin synthesis. Br. J. Haematol., 44: 527-534.

ANTONINI, E. \& BRUNORI, M., 1971, The derivatives of ferrous hemoglobin and myoglobin. In: A. Neuberger \& E. L. Tatum (eds.), Hemoglobin and myoglobin in their reactions with ligands. North-Holland Publishing Company, Amsterdan, London.

ARNONE, A. \& PERUTZ, M. F., 1972, Structure of inositol hexaphosphate-human deoxyhemoglobin complex. Nature, 249: 34-36.

BARTLETT, G., 1980, Phosphate compounds in vertebrate red blood cells. Am. Zoologist, 20: 103-114.

BARTLETT, G., 1976, Phosphate compounds in red cells of reptiles, amphibians and fish. Comp. Biochem. Physiol., 55A: 211-214.

BENESCH, R., BENESCH, R. E. \& YU, C. I., 1968, Reciprocal binding of oxygen and diphosphoglycerate by human hemoglobin. Proc. Nat. Acad. Sci., USA, 59: 526-532.

BONAFÉ, C. F. S., MATSUKUMA, A. Y. \& MATSUURA, M. S. A., 1999, ATP-induced tetramerization and cooperativity in hemoglobin of lower vertebrates. J. Biol. Chem., 274: 1196-1198.

BURGGREN, W., HAHN, C. E. W. \& FOEX, P., 1977, Properties of blood oxygen transport in the turtle Pseudemys scripta and the tortoise Testudo graeca: Effects of temperature, $\mathrm{CO}_{2}$ and pH. Respir. Physiol., 31: 39-50.

CASTAÑO, M., OLGA, V. \& LUGO, M. R., 1981, Estudio comparativo del comportamiento de las especies de morrocoy: Geochelone carbonaria y Geochelone denticulata y aspectos comparables de su morfología externa. Cespedesia, 10: 55-122. 
COATES, M. L., 1975, Hemoglobin function in the vertebrates: An evolutionary model. J. Mol. Evol., 6: 285-307.

DAVIS, B. J., 1964, Disc electrophoresis - II. Method and application to human serum proteins. Ann. N. Y. Acad. Sci,. 121: 404-427.

DAVIS, B. J., 1991, Developmental change in the blood oxygen transport system of Kemps's ridley sea turtle, Lepidochelys kempi. Can. J. Zool., 69: 2660-2666.

FOCESI Jr., A., TAKAGI, M. \& OGO, S. H., 1990, Polyphosphate binding sites in Liophis miliaris hemolgobin. Evidence with reduced nicotinamide adenine dinucleodite phosphate. An. Acad. Bras. Ci., 62: 401-408.

FRETEY, J., 1978, Mesurement de tortues luths femelles adultes, Dermochelys coriacea (Linné), em Guyane Française. Bulletin de la Société Zoologique de France, 103: $518-523$.

LAURENT, T. C. \& KILLANDER, J., 1964, A theory of gel filtration and its experimental verification. J. Chromat., 14: $317-325$.

LUTZ, L. \& LAPENAS, G. N., 1982, Effects of pH, $\mathrm{CO}_{2}$ and phosphates on oxygen affinity of sea turtle hemoglobins. Respir. Physiol., 48: 75-87.

MATSUURA, M. S. A., OGO, S. H. \& FOCESI Jr., A., 1987, Dimer-tetramer transition in hemoglobin from Liophis miliaris. I. Effect of organic polyphosphates. Comp. Biochem. Physiol., 86A: 683-687.

OGO, S. H., ABE, A. S. \& FOCESI Jr., A., 1979, Oxygen dissociation constants in hemoglobins of Helicops modestus and Liophis miliaris, two water-snakes with different morphological adaptations to their aquatic environment. Comp. Biochem. Physiol., 63A: 285-289.

ORNSTEIN, L., 1964, Disc electrophoresis - I. Background and theory. Ann. N. Y. Acad. Sci., 121: 321-349.

REISCHL, E., 1986, High sulfhydryl content in turtle erythrocytes: is there a relation with resistance to hypoxia? Comp. Biochem. Physiol., 85B: 723-726.

REISCHL, E., 1989, Sulfhydryl-rich hemoglobins in reptiles: A defense against reactive oxygen species? In: A. V. Woodhead (ed.), Nonmammalian animal models for biochemical research. CRC Press, Boca Raton.
RIGGS, A. \& WOLBACH, R. A., 1956, Sulfhydryl groups and the structure of hemoglobin. J. General Physiol., 39: 585-605.

RIGGS, A., SUlliVAN, B. \& AGEE, J. R., 1964, Polymerization of frog and turtle hemoglobins. Proc. Nat. Acad. Sci., USA, 51: 1127-1134.

RIGGS, A., 1964, The relation between structure and function in hemoglobins. Can. J. Biochem., 42: 763-775.

RIGGS, A., 1998, Self-association, cooperativity and supercooperativity of oxygen binding by hemoglobin. J. Exper. Biol., 201: 1073-1084.

RUCKNAGEL, K. P., REISCHL, E. \& BRAUNITZER, G., 1984, Hämoglobin der Reptilien. Expression von $\alpha D$ genen bei Schildkröten, Chrysemys picta belii und Phrynops hilarii (Testudines). Hoppe-Seyler's Zeitschrift für Physiologische Chemie, 365: 1163-1171.

SULLIVAN, B. \& RIGGS, A., 1964, Hemoglobin: reversal of oxidation and polymerization in turtle red cells. Nature, 204: 1098-1099.

SULLIVAN, B. \& RIGGS, A., 1967a, Structure, function and evolution of turtle hemoglobins - I. Distribution of heavy hemoglobins. Comp. Biochem. Physiol., 23: 437-447.

SULLIVAN, B. \& RIGGS, A., 1967b, Structure, function and evolution of turtle hemoglobins - II. Electrophoretic studies. Comp. Biochem. Physiol., 23: 449-458.

SVEDBERG, T. \& HEDENIUS, A., 1934, The sedimentation constants of the respiration proteins. Biol. Bull., 66: 191223

TORSONI, M. A., VIANA, R. I., BARROS, B. F., STOPPA, G. R., CESQUINI, M. \& OGO, S. H., 1996, Effect of thiol reagents on functional properties and heme oxidation in the hemoglobin of Geochelone carbonaria. Biochem. Mol. Biol. Intern., 40: 355-364.

TORSONI, M. A., VIANA, R. I., STOPPA, G. R., CESQUINI, M., BARROS, B. F. \& OGO, S. H., 1997, Oxygen binding properties of total hemoglobin and isolated components of the terrestrial tortoise Geochelone carbonaria. Comp. Biochem. Physiol., 118A: 679-684.

WINTERBOURN, C. C., 1990, Oxidative reduction of hemoglobin. Meth. Enzymol., 186: 265-272. 